\title{
Maximizing Students' Scientific Process Skill within Creative Product Design:
}

\author{
Creative Responsibility Based Learning
}

\author{
Suyidno, Dewi Dewantara \\ Faculty of Teacher Training and Education \\ Universitas Lambung Mangkurat, Banjarmasin \\ Banjarmasin, Indonesia \\ suyidno_pfis@unlam.ac.id
}

\author{
Mohamad Nur, Leny Yuanita \\ Universitas Negeri Surabaya \\ Surabaya, Indonesia
}

\begin{abstract}
Physics learning has greatly contributed to the development of technology products. Why do most students face difficultly to design a product creatively? This paper describes the effectiveness of Creative Responsibility Based Learning (CRBL) to maximize the scientific process skill within creative product design. This research was conducted in four classes (physics, chemistry, biology, and science education) Universitas Lambung Mangkurat in 2016. Scientific process skill and creative product design data were obtained from the pre-test and post-test. The data were analyzed by using independent t-test, one-way ANOVA, Tukey test, and bivariate correlation. The tvalue of scientific process skill was $\mathbf{- 1 3 . 1 5 6}$ and the $t$-value of creative product design was $\mathbf{- 1 2 . 6 4 0}$. It indicated that the average of pre-test and post-test was significantly different. The CRBL affected students' scientific process skill and creative product design. Tukey test results also indicated that all groups had no significant difference with one another. F-value of scientific process skill was 1.236 with sig 0.315 , indicated that CRBL increased scientific process skill consistently. F-value of scientific process skill was 3.483 with sig 0.018 , indicated that CRBL increased creative product design consistently. Bivariate correlation test indicated that there was a correlation between scientific process skill and students' creative product design. The correlation was 0.511 . It was concluded that CRBL was effective to maximize the scientific process skill within creative product design. Furthermore, it is recommended that the way to make creative product design is implemented in the daily life.
\end{abstract}

Keywords-Creative Product Design, Creative Responsibility Based Learning, Scientific Process Skill

\section{INTRODUCTION}

Physics is one of fields to which the phenomena or problems in it are related to the daily life [1]. It is the study of the nature matter, energy, symptoms, experienced objects in nature, as well as a foundation the development of science and technology in daily life. As a result, the physics university students must be accustomed to use the scientific process skill in designing any creative product to overcome the effects of the science and technology development. In fact, the scientific process skill has not been integrated in the learning process, so that students' creativity tends to be left [2]. Students face difficulties in making operational definition of variables, planning observational data table, planning experiment procedure, and drawing conclusion [3]. Students also find difficulties in using physics knowledge to design product creatively [4].

Scientific process skill (SPS) is included as an important aspect in physics learning [5]. Students can use the science process skills to construct science [6]. Understanding the SPS further strengthens the responsibility of students in their own learning process [7]. Some of the science process skills used by the scientists are as follows: formulating the problems; formulating the hypotheses; identifying variables; identifying operational variables definition; designing the data observation tables; designing the experimental procedures; conducting the experiments; analyzing the data; and drawing conclusion $[6,8]$. The science process skills contribute $40.1 \%$ to creativity development and $\mathrm{rxy}=0.445$ indicate a very significant correlation between the two variables [9]. Creativity in learning physics is often known by the scientific creativity [10]. Scientific creativity is defined as a kind of intellectual trait or ability to produce or potentially produce a certain product that is original and has social or personal value, designed with a certain purpose in mind, using given information [11]. Scientific creativity is different from general creativity since it is concerned to creative science experiments, creative scientific problem finding and solving, and creative science activity [11][12][13]. The result of scientific creativity is in the form of creative products [14]. Creative products do not have to be an object, but they can be ideas or papers, not necessarily new but can be the result of merging, altering, or adding existing ideas [15].

Various creative learning models can be used to maximize the scientific process skill to design creative products, one of which is Creative Responsibility Based Learning (CRBL) [16]. Creative responsibility means every individual has the responsibility to be creative and the resulting creative product must be individually and socially responsible. CRBL has been developed with the primary objective of increasing responsibility, science process skills, and scientific creativity of students. The responsibility is to do their best behavior during the learning process in terms of participation, respect for others, teamwork, leadership, and expression. Scientific knowledge is the knowledge gained by scientific methods. This method includes formulating the problem, formulating a 
hypothesis, defining variables, defining the operational definition of variables, creating tables and having experiments procedure, analyzing and drawing conclusions. Science creativity includes unusual uses, problem finding, product improvement, scientific imagination, creative science problem solving, creative experiment design, and creative product design [11][16][17]. CRBL development has a foundation of cognitive learning theory, complex cognitive processes theory, learning theory and social-cognitive constructivism theory [16]. Syntax of CRBL is summarized on Table 1 [16].

\section{TABLE I. THE SYNTAX OF CRBL}

\begin{tabular}{|c|c|}
\hline Lecturer Activities & Student Activities \\
\hline \multicolumn{2}{|c|}{ Phase 1: Generating student's creative responsibility } \\
\hline $\begin{array}{l}\text { 1. Motivating students by } \\
\text { asking unusual use } \\
\text { questions. } \\
\text { 2. Communicating the } \\
\text { purpose of learning and } \\
\text { the importance of the } \\
\text { creative responsibility in } \\
\text { life. }\end{array}$ & $\begin{array}{l}\text { 1. Providing answers to unusual use } \\
\text { questions the given faculty. } \\
\text { Listening to the lecturers' } \\
\text { explanation carefully to understand } \\
\text { the purpose of learning and the } \\
\text { importance of personal } \\
\text { responsibility to be creative. }\end{array}$ \\
\hline \multicolumn{2}{|c|}{ Phase 2: Organizing a creative learning needs } \\
\hline 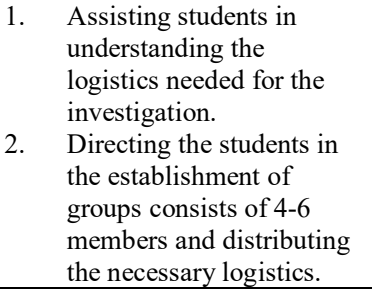 & 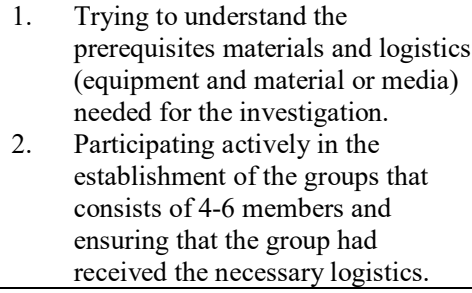 \\
\hline \multicolumn{2}{|c|}{ Phase 3: Guiding Investigation Group } \\
\hline $\begin{array}{l}\text { Developing a student's sense } \\
\text { of responsibility in the } \\
\text { activities of the experiment and } \\
\text { analyzing various sources of } \\
\text { information referring to the } \\
\text { worksheet to solve scientific } \\
\text { problems creatively. }\end{array}$ & $\begin{array}{l}\text { Trying to develop a sense of } \\
\text { responsibility (participation, respect for } \\
\text { others, teamwork, leadership, and } \\
\text { expression) in understanding the } \\
\text { problems of science, defined the } \\
\text { formulation of the problem that they } \\
\text { want to search, plan, and carry out } \\
\text { experiments, and analyzing various } \\
\text { resources to solve scientific problems } \\
\text { creatively. }\end{array}$ \\
\hline \multicolumn{2}{|c|}{ Phase 4: Establishing responsibility in showing scientific creativity } \\
\hline $\begin{array}{l}\text { Giving responsibility to the } \\
\text { students to make some } \\
\text { assessment of scientific } \\
\text { creativity and its completion, } \\
\text { and then discussing the results } \\
\text { of the group's performance in } \\
\text { front of the class. }\end{array}$ & $\begin{array}{l}\text { Trying to accept and carry out the } \\
\text { responsibility (participation, respect for } \\
\text { others, teamwork, leadership, and } \\
\text { expression) to make some assessment of } \\
\text { the scientific creativity (unusual uses, } \\
\text { problem finding, scientific imagination, } \\
\text { product improvement, creative science } \\
\text { problem solving, creative experiment } \\
\text { designing, and creative product design) } \\
\text { along with the settlement refers to } \\
\text { examples of scientific creativity votes } \\
\text { given, then presented the results of the } \\
\text { group's performance in front of the class }\end{array}$ \\
\hline \multicolumn{2}{|c|}{ Phase 5: Evaluation and Reflection } \\
\hline $\begin{array}{l}\text { Helping students to evaluate } \\
\text { learning outcomes and learning } \\
\text { process reflecting to its follow- } \\
\text { up }\end{array}$ & $\begin{array}{l}\text { Participating in the evaluation of } \\
\text { understanding their scientific creativity } \\
\text { and a responsibility, reflection of the } \\
\text { learning process has done its follow-up. }\end{array}$ \\
\hline
\end{tabular}

CRBL requires learning environment investigations in a free, open, democratic and positive, involving as many scientific questions, appreciating the variety of products of imagination, innovation, and bravely accepting advice and criticism. This also provides the opportunity of cooperation and imagination to produce new and unique ideas in solving the problem. The implementation of CRBL facilitates students in solving problems, understanding the world they live in, adapting to changing societies, and designing new technologies to achieve goals [16].

\section{METHOD}

This is an educational research which was conducted in physics education, chemistry education, biology education, and science education of Universitas Lambung Mangkurat in 2016. This research was conducted in the fundamental physics course. The creative process was maximized by using a worksheet that can construct the scientific knowledge. This worksheet was developed based on the CRBL. Students creative process data were obtained based on the worksheet. The data were analyzed using independent t-test to determine the differences in the creative process of constructing scientific knowledge of before and after using the CRBL. Further, the difference between the creative process between one class and another was tested by using one-way ANOVA followed by Tukey test.

\section{RESULTS AND DISCUSSION}

\section{A. Studenst' Science Process Skill}

The data on the students' science process skill in this study were obtained from the pretest and posttest results. The entire scores of the four classes (physics education, chemistry education, biology education, and science education) were accumulated. The pretest result was compared to the posttest results using paired t-test. The following is the result of the paired t-test using SPSS 22.0 program.

TABLE II. THE STATISTICAL DESCRIPTION OF THE PRETEST AND POSTTEST SCORES

\begin{tabular}{|l|l|l|c|l|l|}
\hline \multicolumn{2}{|c|}{} & \multicolumn{1}{|c|}{ Mean } & N & $\begin{array}{c}\text { Std. } \\
\text { Deviation }\end{array}$ & $\begin{array}{c}\text { Std. Error } \\
\text { Mean }\end{array}$ \\
\hline $\begin{array}{l}\text { Pair } \\
1\end{array}$ & Pretest & 13.645 & 32 & 14.502 & 2.564 \\
\cline { 2 - 6 } & Posttest & 72.188 & 32 & 25.422 & 4.494 \\
\hline
\end{tabular}

Table 2 is a statistical description of the pretest and posttest scores. The average pretest score was 13.65 with 14.5 standard deviation and 2.56 standard error of the mean. The average posttest score was 72.19 with a standard deviation of 25.42 and standard error of the mean of 4.49. The analysis showed that the average pretest score was higher than the average posttest score.

TABLE III. The Correlation Between Pretest And Posttest

\begin{tabular}{|l|l|c|l|c|}
\hline \multicolumn{2}{|l|}{} & N & Correlation & Sig. \\
\hline Pair 1 & Pretest \& Posttest & 32 & .302 & .093 \\
\hline
\end{tabular}

Table 3 shows that the correlation between pretest and posttest was 0.302 with a sig. of 0.093 . This shows that the correlation between the average score of pretest and posttest was strong and significant. The hypotheses of this analysis are: 
$\mathrm{H}_{\mathrm{o}}$ : the average scores of pretest and posttest are the same; $\mathrm{H}_{1}$ : the average scores of pretest and posttest are different. The hypothesis test results are shown in Table 4 below.

TABLE IV. PAIRED DIFFERENCES BETWEEN PRETEST AND POSTTEST

\begin{tabular}{|c|c|c|c|c|c|c|c|c|c|}
\hline & \multicolumn{5}{|c|}{ Paired Differences } & \multirow{3}{*}{$T$} & \multirow{3}{*}{$d f$} & \\
\hline & & \multirow[t]{2}{*}{ Mean } & \multirow[t]{2}{*}{$\begin{array}{c}\text { Std. } \\
\text { Deviation }\end{array}$} & \multirow{2}{*}{$\begin{array}{l}\text { Std. } \\
\text { Error } \\
\text { Mean }\end{array}$} & \multicolumn{2}{|c|}{$\begin{array}{l}\text { 95\% Confidence } \\
\text { Interval of the } \\
\text { Difference }\end{array}$} & & & $\mid \begin{array}{c}\text { stg. } \\
(2- \\
\text { tailed })\end{array}$ \\
\hline & & & & & Lower & Upper & & & \\
\hline $\begin{array}{l}\text { Pair } \\
1\end{array}$ & $\begin{array}{l}\text { Pre } \\
\text { test } \\
- \\
\text { Post } \\
\text { test }\end{array}$ & 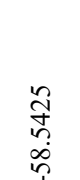 & $\frac{m}{\frac{m}{2}}$ & 享 & 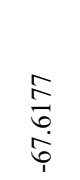 & 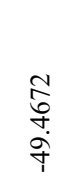 & $\stackrel{\circ}{\dddot{n}}$ & $\vec{m}$ & 8 \\
\hline
\end{tabular}

Table 4 shows that the t value was -13.156 ; with sig. 0,000 . As the level of significance was $<0.05$, it can be concluded that $\mathrm{H}_{\mathrm{o}}$ was rejected, meaning that the average scores of pretest and posttest were different. Thus, it can be stated that the CRBL model affected students in the science process skill of constructing scientific knowledge.

Based on this analysis, each phase in the CRBL student is able to maximize the science process skill. This can be seen from the increasing ability of students in formulating the problem, formulating a hypothesis, defining variables, defining the operational definition of variables, creating tables and experiments procedures, analyzing and drawing conclusions. Inquiry-based physics learning and fun activities aim to empower and motivate students to control their own learning [18].

TABLE V. STUDENTS'SCIENCE PROCESS SKILl IN EACH CLASS

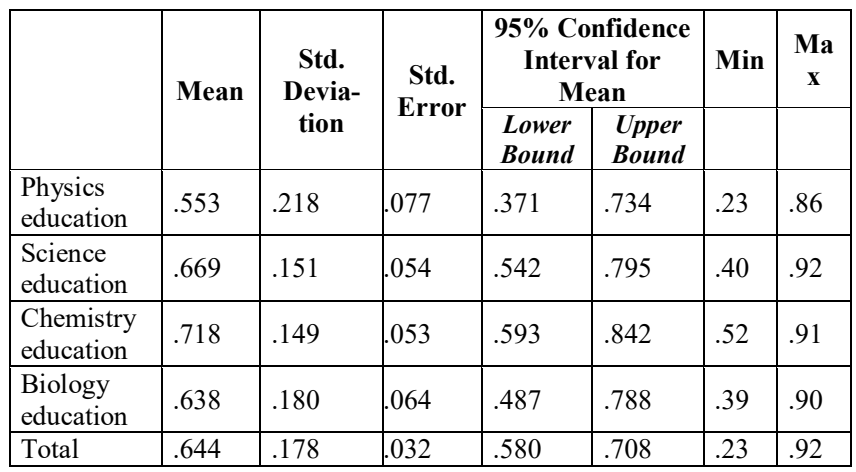

Table 5 shows the description of the acquisition gain score in four classes. The table shows that the average gain score of chemistry education was the highest 0.7175 . The difference between pretest and posttest scores in chemistry education the highest among the others.

TABLE VI. The ANOVA TEST RESUlt FOR THE SCIENCE Process SKILL

\begin{tabular}{|l|l|l|l|l|l|}
\hline & $\begin{array}{c}\text { Sum of } \\
\text { Squares }\end{array}$ & \multicolumn{1}{|c|}{ df } & \multicolumn{1}{|c|}{ Mean Square } & F & Sig. \\
\hline $\begin{array}{l}\text { Between } \\
\text { groups }\end{array}$ & .115 & 3 & .038 & 1.236 & .315 \\
\hline $\begin{array}{l}\text { Within } \\
\text { groups }\end{array}$ & .872 & 28 &, 031 & & \\
\hline Total & .987 & 31 & & & \\
\hline
\end{tabular}

The analysis using ANOVA aims to find whether there are differences in the average of science process skills in physical, science, chemistry, and biology education classes. The hypotheses are: Ho: The average of the entire population is identical; $\mathrm{H}_{1}$ : The average of the entire population is not identical. Table 6 shows that $\mathrm{F}$ was 1,236 with probability or sig 0.315 . As the probability value $<0.05$, Ho was rejected. The conclusion of this test is that the four average classes are different. Despite getting the same treatment, the results obtained by the chemistry study program were the highest. While the gain score obtained by the physical education students was not too high. Nevertheless, it appears that in all four courses there was an increase in the score on pretest and posttest. CRBL has developed to enhance the science process skills and scientific creativity [19].

TABLE VII. COMPARISON OF GAIN SCORE IN EACH CLASS

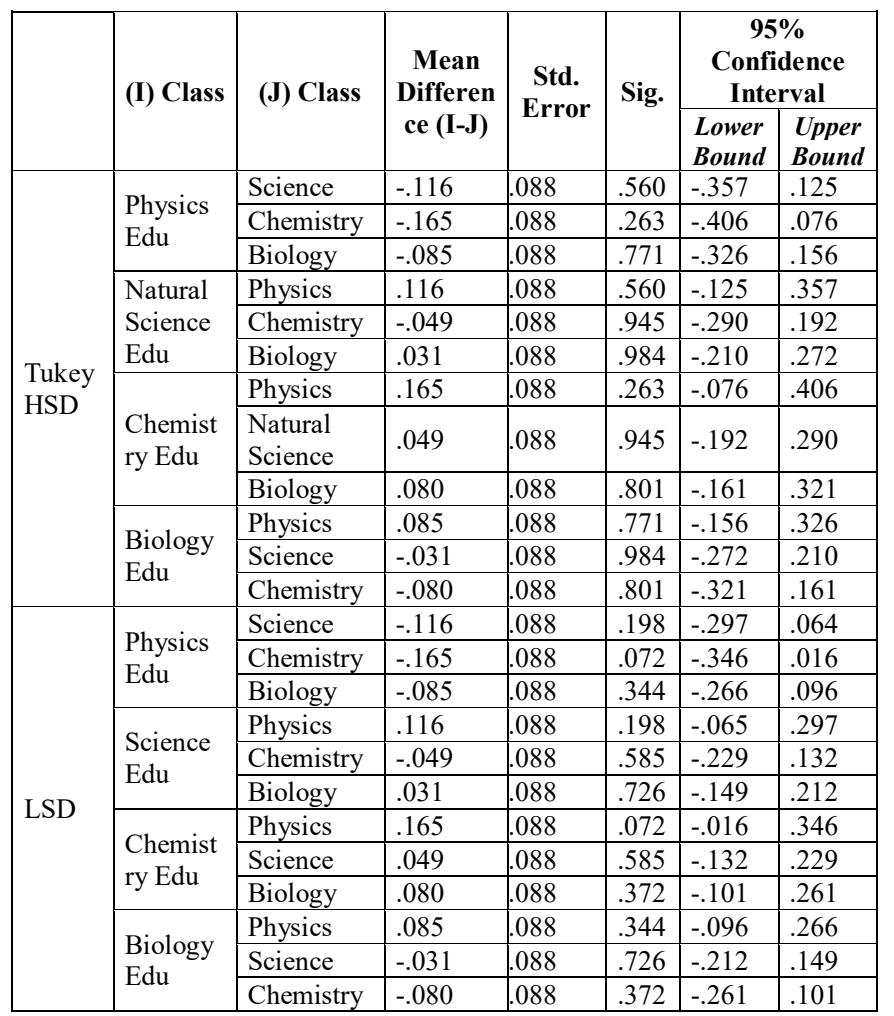

Homogeneous Subset in table 8 shows which groups have different meanings that do not differ significantly. The following table shows the Homogeneous Subsets data.

TABLE VIII. HOMOGENEOUS SUBSET OF STUDENTS' SCIENCE PROCESS SKILLS

\begin{tabular}{|c|c|c|c|}
\hline & \multirow[t]{2}{*}{ Class } & \multirow[t]{2}{*}{$\mathbf{N}$} & $\begin{array}{c}\text { Subset for } \\
\text { alpha }=0.05\end{array}$ \\
\hline & & & 1 \\
\hline \multirow{5}{*}{ Tukey HSD ${ }^{a}$} & Physics Edu & 8 & .553 \\
\hline & Biology Edu & 8 & .638 \\
\hline & Science Edu & 8 & .669 \\
\hline & Chemistry Edu & 8 & .718 \\
\hline & Sig. & & .263 \\
\hline \multicolumn{4}{|c|}{ Means for groups in homogeneous subsets are displayed. } \\
\hline \multicolumn{4}{|c|}{ a. Uses Harmonic Mean Sample Size $=8,000$. } \\
\hline
\end{tabular}


Table 8 shows that all groups did not show any significant difference to each other. This suggests that the results obtained by the four courses after applying the CRBL are the same. The probability value was 0.263 . Since there was no difference, the CRBL model had the same effect on all sample groups. This means that the CRBL is able to maximize students' science process skills. The CRBL motivates students to try to cultivate a sense of responsibility (participate, respect others, cooperate, lead, express opinions, and solicit help) in understanding science issues, naming as many problems as possible and isolating any formulation of issues to investigate, conduct experiments, as well as review various sources of information to solve scientific problems creatively. Important recommendations of self-regulation, depth instruction in the exploration, openness of ideas, evaluate ideas, and increased attention to the nature of contemporary science and its application is an important part in the development of characteristics model. The cognitivist and constructivism views have been applied through analyzing the activity of the task, managing gradual problem solving, setting goals and measuring performance based on objectives, and promoting a learning experience that is more open [19].

\section{B. Students' Creative Product Design}

The data on students' creative product design were obtained from the pretest and posttest results. All classes scores were accumulated. The pretest result was compared to the results of the posttest using paired t-test. The result of the paired t-test using SPSS 22.0 program is as follows.

TABLE IX. THE STATISTICAL DESCRIPTION OF THE PRETEST AND POSTTEST SCORES

\begin{tabular}{|l|l|l|l|l|l|}
\hline \multicolumn{2}{|c|}{} & Mean & N & $\begin{array}{c}\text { Std. } \\
\text { Deviation }\end{array}$ & $\begin{array}{c}\text { Std. Error } \\
\text { Mean }\end{array}$ \\
\hline \multirow{2}{*}{$\begin{array}{l}\text { Pair } \\
1\end{array}$} & $\begin{array}{l}\text { Pretest creative } \\
\text { product design }\end{array}$ & 4.7667 & 120 & 2.161 & .197 \\
\cline { 2 - 6 } & $\begin{array}{l}\text { Posttest creative } \\
\text { product design }\end{array}$ & 7.9667 & 120 & 3.202 & .292 \\
\hline
\end{tabular}

Table 9 shows the average pretest score was 4.7667 with the standard deviation of 2.1605 and the standard error of the mean of 0.1972 . The average posttest score was 7.9667 with the standard deviation of 3.2017 and the standard error of the mean of 0.2923 . The analysis showed that the average pretest score was higher than the average score of posttest.

TABLE X. CORRELATION BETWEEN PRETEST AND POSTTEST

\begin{tabular}{|l|l|l|l|l|}
\hline \multicolumn{2}{|c|}{} & \multicolumn{1}{|c|}{ N } & Correlation & Sig. \\
\hline $\begin{array}{l}\text { Pair } \\
1\end{array}$ & $\begin{array}{l}\text { Pretest \& posttest } \\
\text { creatively product } \\
\text { design }\end{array}$ & 120 & .522 & .000 \\
\hline
\end{tabular}

Table 10 shows that the correlation between pretest and posttest was 0.522 with a sig. of 0.000 . This shows that the correlation between the average score of pretest and posttest is also strong and significant. The hypotheses of this analysis are: $\mathrm{H}_{\mathrm{o}}$ : the average scores of pretest and posttest are the same; $\mathrm{H}_{1}$ $:$ the average scores of pretest and posttest are different. The hypothesis test results shown in the table below:
TABLE XI. THE PAIRED DIFFERENCES BETWEEN PRETEST AND POSTTEST

\begin{tabular}{|c|c|c|c|c|c|c|c|c|}
\hline & \multicolumn{5}{|c|}{ Paired Differences } & \multirow{3}{*}{$\mathbf{t}$} & \multirow{3}{*}{$\begin{array}{l}\text { Sig. (2 } \\
\text { tailed) }\end{array}$} \\
\hline & & \multirow[t]{2}{*}{ Mean } & \multirow{2}{*}{$\begin{array}{c}\text { Std. } \\
\text { Devia } \\
\text { tion }\end{array}$} & \multirow{2}{*}{$\begin{array}{l}\text { Std. } \\
\text { Error } \\
\text { Mean }\end{array}$} & \multicolumn{2}{|c|}{$\begin{array}{l}\text { 95\% Confidence } \\
\text { Interval of the } \\
\text { Difference }\end{array}$} & & \\
\hline & & & & & Lower & Upper & & \\
\hline $\begin{array}{l}\text { Pair } \\
1\end{array}$ & $\begin{array}{l}\text { Pretest- } \\
\text { posttest } \\
\text { creative } \\
\text { product } \\
\text { design }\end{array}$ & $\begin{array}{l}\text { ¿ } \\
\text { ஸे } \\
\text { i }\end{array}$ & $\stackrel{\Re}{\stackrel{2}{i}}$ & $\stackrel{\overbrace{}}{\tilde{n}}$ & $\underset{\vec{R}}{\vec{p}}$ & $\begin{array}{l}\hat{g} \\
\text { ì }\end{array}$ & 엄 & 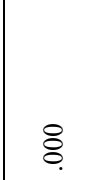 \\
\hline
\end{tabular}

The $\mathrm{t}$ value was -12.640 ; with sig. 0.000 . It can be concluded that $\mathrm{H}_{\mathrm{o}}$ was rejected, meaning that the average score of pretest and posttest is different. Thus, the CRBL affects the students in the creative product design. Based on this analysis, each phase in the CRBL student is able to maximize the creative product design. Competency framework of the $21 \mathrm{st}$ century has not only mastered the core subject, but also included the learning skills and innovation (critical thinking, communication, collaboration, and creativity), life skills and career (flexible and adaptive, initiative and independence, social skills and cultural, productive and accountability, leadership and responsibility), skills in using information, media, and technology [20]. The CRBL is able to influence the creative process of students in constructing scientific knowledge. The application of CRBL is able to increase the quality of the learning process and the quality of higher education graduates. The learning process has been able to provide space for the development of creativity, initiative, personality, and self-reliance in the search for and find the knowledge [21].

TABle XiI. Students' Creative Product Design Skill In Each CLASS

\begin{tabular}{|c|c|c|c|c|c|c|c|}
\hline & \multirow[t]{2}{*}{ Mean } & \multirow{2}{*}{$\begin{array}{c}\text { Std. } \\
\text { Deviatio } \\
\mathbf{n}\end{array}$} & \multirow{2}{*}{$\begin{array}{l}\text { Std. } \\
\text { Err } \\
\text { or }\end{array}$} & \multicolumn{2}{|c|}{$\begin{array}{c}\text { 95\% Confidence } \\
\text { Interval for } \\
\text { Mean }\end{array}$} & \multirow[t]{2}{*}{ Min } & \multirow[t]{2}{*}{ Max } \\
\hline & & & & $\begin{array}{l}\text { Lower } \\
\text { Bound }\end{array}$ & $\begin{array}{l}\text { Upper } \\
\text { Bound }\end{array}$ & & \\
\hline $\begin{array}{l}\text { Physics } \\
\text { Edu }\end{array}$ & 1.848 & 1.840 & .336 & 1.161 & 2.535 & -2.33 & 5.94 \\
\hline $\begin{array}{l}\text { Science } \\
\text { Edu }\end{array}$ & 2.941 & 3.530 & 644 & 1.623 & 4.259 & -4.50 & 8.89 \\
\hline $\begin{array}{l}\text { Chemistry } \\
\text { Edu }\end{array}$ & 2.844 & 2.761 & .504 & 1.814 & 3.875 & -1.28 & 9.89 \\
\hline $\begin{array}{l}\text { Biology } \\
\text { Edu }\end{array}$ & 4.107 & 2.446 & .447 & 3.194 & 5.021 & -.39 & 8.72 \\
\hline Total & 2.935 & 2.797 & .255 & 2.430 & 3.441 & -4.50 & 9.89 \\
\hline
\end{tabular}

Table 12 shows the description of the acquisition gain score in four classes. The table shows that the average gain score of biology education class was the highest with 4.1074. This shows that the difference between pretest and posttest scores in biology education was the highest among the others.

TABLE XIII. RESULTS OF ANOVA TEST FOR THE CREATIVE PRODUCT DESIGN

\begin{tabular}{|l|l|l|l|l|l|}
\hline & $\begin{array}{c}\text { Sum of } \\
\text { Squares }\end{array}$ & \multicolumn{1}{|c|}{ Df } & $\begin{array}{c}\text { Mean } \\
\text { Square }\end{array}$ & F & Sig. \\
\hline Between groups & 76.921 & 3 & 25.640 & 3.483 & .018 \\
\hline Within groups & 853.927 & 116 & 7.361 & & \\
\hline Total & 930.848 & 119 & & & \\
\hline
\end{tabular}


The analysis of using ANOVA aims to find whether there are differences in the average of science process skills in physical education classes, science, chemistry, and biology. The hypotheses for this case are: $\mathrm{H}_{0}$ : the four average populations are identical; $\mathrm{H}_{1}$ : The four average populations are not identical. Table 13 shows that $\mathrm{F}$ was 3.483 with probability or sig. 0.018 . Because the probability value $<0.05$, then Ho was rejected. The conclusion of this test is that the four average courses were different. Nevertheless, it appears that in all four courses there was an increase in the score on pretest and posttest. CRBL has been developed not only to enhance the science process skills, and scientific creativity, but also the attitude of student responsibility that will contribute directly to the development of scientific creativity [19]. Here is the comparison of gain score on each course.

TABLE XIV. COMPARISON OF GAIN SCORE IN EACH STUDY PROGRAM

\begin{tabular}{|c|c|c|c|c|c|c|c|}
\hline & \multirow{2}{*}{ (I) Class } & \multirow{2}{*}{ (J) Class } & \multirow{2}{*}{$\begin{array}{c}\text { Mean } \\
\text { Differen } \\
\text { ce (I-J) }\end{array}$} & \multirow{2}{*}{$\begin{array}{l}\text { Std. } \\
\text { Error }\end{array}$} & \multirow{2}{*}{ Sig. } & \multicolumn{2}{|c|}{$\begin{array}{l}\text { 95\% Confidence } \\
\text { Interval }\end{array}$} \\
\hline & & & & & & $\begin{array}{l}\text { Lower } \\
\text { Bound }\end{array}$ & $\begin{array}{l}\text { Upper } \\
\text { Bound }\end{array}$ \\
\hline \multirow{12}{*}{$\begin{array}{l}\text { Tukey } \\
\text { HSD }\end{array}$} & \multirow{3}{*}{$\begin{array}{l}\text { Physics } \\
\text { Edu }\end{array}$} & Science & -1.093 & .701 & .406 & -2.919 & .734 \\
\hline & & Chemistry & -.996 & .701 & .488 & -2.822 & .830 \\
\hline & & Biology & $-2.259^{*}$ & 7.701 & .009 & -4.085 & -.433 \\
\hline & \multirow{3}{*}{$\begin{array}{l}\text { Science } \\
\text { Edu }\end{array}$} & Physics & 1.093 & .701 & .406 & -.734 & 2.919 \\
\hline & & Chemistry & .096 & .701 & .999 & -1.730 & 1.922 \\
\hline & & Biology & -1.167 & 7.701 & .347 & -2.993 & $\begin{array}{l}.659 \\
\end{array}$ \\
\hline & \multirow{3}{*}{$\begin{array}{l}\text { Chemistry } \\
\text { Edu }\end{array}$} & Physics & .996 & .701 & .488 & -.830 & 2.822 \\
\hline & & Science & -.096 & .701 & .999 & -1.922 & 1.730 \\
\hline & & Biology & -1.263 & .701 & .277 & -3.089 & .563 \\
\hline & \multirow{3}{*}{$\begin{array}{l}\text { Biology } \\
\text { Edu }\end{array}$} & Physics & $2.259^{*}$ & .701 & .009 & .433 & 4.085 \\
\hline & & Science & 1.167 & .701 & \begin{tabular}{|l|}
.347 \\
\end{tabular} & -.659 & 2.993 \\
\hline & & Chemistry & 1,263 & .701 & .277 & -.563 & 3.089 \\
\hline \multirow{12}{*}{ LSD } & \multirow{3}{*}{$\begin{array}{l}\text { Physics } \\
\text { Edu }\end{array}$} & Science & -1.093 & .701 & .122 & -2.480 & .295 \\
\hline & & Chemistry & -.996 & .701 & .158 & -2.384 & .391 \\
\hline & & Biology & $-2.259^{*}$ & .701 & .002 & -3.647 & -.872 \\
\hline & \multirow{3}{*}{$\begin{array}{l}\text { Science } \\
\text { Edu }\end{array}$} & Physics & 1.093 & .701 & .122 & -.295 & 2.480 \\
\hline & & Chemistry & .096 & .701 & .891 & -1.291 & 1.484 \\
\hline & & Biology & -1.167 & .701 & .099 & -2.554 & .221 \\
\hline & \multirow{3}{*}{$\begin{array}{l}\text { Chemistry } \\
\text { Edu }\end{array}$} & Physics & .996 & .701 & .158 & -.391 & 2.384 \\
\hline & & Science & -.096 & .701 & .891 & -1.484 & \begin{tabular}{|l|}
1.291 \\
\end{tabular} \\
\hline & & Biology & -1.263 & .701 & .074 & -2.650 & .125 \\
\hline & \multirow{3}{*}{$\begin{array}{l}\text { Biology } \\
\text { Edu }\end{array}$} & Physics & $2.259^{*}$ & .701 & .002 & .872 & 3.647 \\
\hline & & Science & 1.167 & .701 & .099 & -.221 & 2.554 \\
\hline & & Chemistry & 1.263 & .701 & .074 & -.125 & 2.651 \\
\hline
\end{tabular}

Homogeneous Subset in Table 14 shows which groups have different meanings that do not differ significantly. The following table shows Homogeneous Subsets.

TABLE XV. HOMOGENEOUS SUBSET OF STUDENT'S CREATIVELY PRODUCT DESIGN SKILL

\begin{tabular}{|c|c|c|c|c|}
\hline & \multirow[t]{2}{*}{ Class } & \multirow[t]{2}{*}{$\mathbf{N}$} & \multicolumn{2}{|c|}{$\begin{array}{c}\text { Subset for alpha }= \\
0.05\end{array}$} \\
\hline & & & 1 & 2 \\
\hline \multirow{5}{*}{$\begin{array}{l}\text { Tukey } \\
\text { HSD }^{\mathrm{a}}\end{array}$} & Physics Edu & 30 & 1.8481 & \\
\hline & Chemistry Edu & 30 & 2.8444 & 2.8444 \\
\hline & Science Edu & 30 & 2.9407 & 2.9407 \\
\hline & Biology Edu & 30 & & 4.1074 \\
\hline & Sig. & & .406 & .277 \\
\hline
\end{tabular}

The table shows that the whole group had no significant differences with each other. This suggests that the results obtained by the four courses after applying the CRBL are the same. Because there was no difference, the CRBL model had the same effect on the entire sample group. This means that CRBL is able to maximize student's creatively product design skill.

\section{Student's Scientific Process Skill Within Creatively Product Designing}

The next stage of analysis is to find the correlation relationship between the results of scientific process skill and creative product design. The correlation results are shown in Table 16.

TABLE XVI. CORRELATION BETWEEN THE RESULTS OF SCIENTIFIC Process SkILl AND Creative Product DeSIGNING

\begin{tabular}{|l|l|l|l|}
\hline \multicolumn{2}{|c|}{} & $\begin{array}{c}\text { Creatively } \\
\text { Product } \\
\text { Design }\end{array}$ & $\begin{array}{c}\text { Scientific } \\
\text { Process Skill }\end{array}$ \\
\hline \multirow{2}{*}{$\begin{array}{l}\text { CREATIVELY } \\
\text { PRODUCT }\end{array}$} & Pearson Correlation & 1 & .511 \\
\cline { 2 - 4 } DESIGN & Sig. (2-tailed) & & .489 \\
\cline { 2 - 4 } & $\mathrm{N}$ & 4 & 4 \\
\hline $\begin{array}{l}\text { SCIENTIFIC } \\
\text { PROCESS } \\
\text { SKILL }\end{array}$ & Pearson Correlation & .511 & 1 \\
\cline { 2 - 4 } & Sig. (2-tailed) & .489 & \\
\cline { 2 - 4 } & $\mathrm{N}$ & 4 & 4 \\
\hline
\end{tabular}

Bivariate correlation test shows that there is a correlation between science process skill and creative product design. The correlation is 0,511 . However, it is not significant. This shows that $C R B L$ is able to maximize the scientific process skill, and with this increase, students' creative product design can also be maximized. CRBL requires learning environment investigations in a free, open, democratic and positive, involving as many scientific questions, appreciate the variety of products of imagination, innovation bravely accept advice and criticism. This model also provides the opportunity of cooperation and imagination to produce new and unique ideas in solving the problem. The application of CRBL is able to increase the quality of the learning process and the quality of higher education graduates. The learning process has been able to provide space for the development of creativity, initiative, personality, and self-reliance in the search for and find the knowledge [21]. The graduates of higher education have the responsibility to master the scientific fields and apply them in solving problems and adapt to the situation at hand [22].

\section{CONCLUSION}

The obtained conclusion is that CRBL is able to maximize the scientific process skill within the creative product design. Based on the descriptive statistical analysis, it is seen that the CRBL affects students' science process skill and creative product designing. Tukey test results also indicated that all groups had no significant difference with one another. The Fvalue of scientific process skill was 1.236 with sig. 0.315 , indicated that $\mathrm{CRBL}$ increasing science process skill consistently. F-value of scientific process skill was 3.483 with sig. 0.018, indicated that CRBL increased creative product designing consistently. Bivariate correlation test indicate that 
there is a correlation between science process skill dan cretive product designing. The correlation is 0.511 . Furthermore, it is recommended that the way to make creative product design for students is implemented in the daily life.

\section{REFERENCES}

[1] H. D. Young, and R. A. Friedmen, "Sears and Zemansky's: University physics with modern physics, 13th edition", San Fransisco: AddisonWesley, 2012.

[2] Higher Education Team, "Buku kurikulum pendidikan tinggi", Direktorat Pembelajaran dan Kemahasiswaan, Direktorat Jenderal Pendidikan Tinggi, Kementerian Pendidikan dan Kebudayaan, 2012.

[3] M. A. Jamal., and Suyidno, "Pemahaman kreativitas, keterampilan proses, dan sikap kreatif mahasiswa melalui pembelajaran kreatif pada matakuliah fisika dasar", Prosiding Seminar Nasional_Program Studi Pendidikan Sains Pascasarjana Universitas Negeri Surabaya, 24 Januari 2015, pp. 361-369.

[4] Suyidno and M. Nur, "Pemahaman kreativitas ilmiah mahasiswa dalam pembelajaran kreatif pada matakuliah fisika dasar", Prosiding Seminar Nasional Program Studi Pendidikan Sains Pascasarjana Universitas Negeri Surabaya, 24 Januari 2015, pp. 1361-1366.

[5] K. N. In, and O. Thongperm, Teaching of science process skills in thai contexts: Status, supports and obstacles. Procedia - Social and Behavioral Sciences, 141, 2014, pp. 1324 - 1329.

[6] F. Karsli, and A. Ayas, "Developing a laboratory activity by using 5e learning model on student learning of factors affecting the reaction rate and improving scientific process skills", Procedia-Social and Behavioral Sciences, 143, 2014, pp. $663-668$.

[7] S. Karamustafaoğlu, "Improving the science process skills ability of science student teachers using i diagrams", Eurasian of Journal Physics and Chemistry Education, 3(1), 2011, pp. 26-38.

[8] M. Nur, "Modul Keterampilan-Keterampilan Proses Sains", Surabaya: Pusat Sains dan Matematika Sekolah, Universitas Negeri Surabaya, 2011.

[9] Y. S. Sari, "Pengaruh keterampilan proses IPA dan motivasi belajar siswa terhadap kreativitas belajar", Jurnal Elementary, 2, 2016, pp. 8391.
[10] R. Mukhopadhyay, and M.K. Sen, "Investigation of creativity in physics in the context of learning in association with deep approach to study", Journal of Humanities and Social Science, 4(2), 2012, pp. 24-30.

[11] W. Hu, and P. Adey, "A scientific creativity test for secondary school students", International Journal of Science Education, 24(4), 2010, pp. 389-403.

[12] H. Raj, and D. R. Saxena, "Scientific creativity: A review of researches", European Academic Research, 4, 2016, pp. 1122-1138.

[13] N. M. Siew, C. L. Chong, and K.O. Chin, "Developing a scientific creativity test for fifth graders", Problems of Education in The 21st Century, 62, 2014, pp. 109-123.

[14] M. Nur, "Berpikir Kreatif", Universitas Negeri Surabaya, Penelitian Unggulan Perguruan Tinggi, 2014.

[15] M. Sudarma, "Mengembangkan Keterampilan Berpikir Kreatif", Jakarta: Rajawali Press, 2012.

[16] Suyidno, M. Nur, L. Yuanita, and B. K. Praharani, "Validity of creative responsibility based learning: An innovative physics learning to prepare the generation of creative and responsibility", Journal of Research \& Method in Education, 7(1), 2017, pp. 56-61.

[17] W. Hu, B. Wu, X. Jia, X. Yi, C. Duan, and W. Meyer, "Increasing student's scientific creativity: The "learn to think" intervention program", The Journal of Creative Behavior, 47(1), 2013, pp. 3-21.

[18] S. C. Liu and H. S. Lin, "Primary teachers' beliefs about scientific creativity in the classroom context", International Journal of Science Education, 36(10), 2013, pp. 1551-1567.

[19] M. F Aqda, F. Hamidi, and F. Ghorbandordinejad, "The impact of constructivist and cognitive distance instructional design on the learner's creativity", Procedia Computer Science, 3, 2010, pp. 260-265.

[20] L. Kellogg, K. Hurley, and K. Kip, The partnership for 21st century Skills", 2011.

[21] Regulation of the Minister of Research, Technology and Higher Education Number 44 of 2015 on "Standar Nasional Pendidikan Tinggi".

[22] Presidential Regulation No. 8 of 2012 on "Kerangka Kualifikasi Nasional Indonesia”. 